\title{
Case Report: A nine year follow-up for a pacemaker generator poly-tetra-fluoro-ethylene coating for allergic reactions to
}

\section{pacemaker compounds [version 1; peer review: 2 approved}

\section{with reservations]}

\author{
Mehdi Slim(iD1, Elies Neffati1 ${ }^{1}$ Afef Lagren1', Kortas Chokri², Amine Tarmiz², \\ Rym Gribba1, Essia Boughzela1 \\ ${ }^{1}$ Department of Cardiology, Sahloul University Hospital, Sousse, 4011, Tunisia \\ ${ }^{2}$ Department of Thoracic and Cardiovascular Surgery, Sahloul University Hospital, Sousse, 4011, Tunisia
}

V1 First published: 13 Sep 2018, 7:1460
https://doi.org/10.12688/f1000research.16014.1

Latest published: 13 Sep 2018, 7:1460

https://doi.org/10.12688/f1000research.16014.1

\begin{abstract}
Background: Allergic reaction to pacemaker compounds is a rare complication of cardiac pacing. Initial management is difficult because accurate diagnosis is often delayed. The tendency is to initially suspect a bacterial infection, rather than to quickly rule out an allergy to the pacemaker components. Management of this condition is difficult and not well established.

Case presentation: A 75-year-old man underwent a dual chamber pacemaker implantation. The patient needed two generator reimplantations because of sterile skin necrosis. Pace maker allergic reaction was suspected despite non-conclusive skin patch testing. The patient underwent pacemaker system removal and re-implantation of poly-tetra-fluoro-ethylene sheet coated generator in a retropectoral position. Subsequently, there has been no externalization or recurrence in nine years of follow-up.

Take-away lesson: Contact allergy to pacemakers is often unrecognized. Once infection has been excluded, allergy testing must be performed. The only valuable treatment is the removal of all the system components, followed by a replacement with hypoallergenic material. Polytetrafluoroethylene coated materials can be effective to prevent recurrence.
\end{abstract}

\section{Keywords}

Contact dermatitis - Cardiac Pacemaker - Patch Tests -

Polytetrafluoroethylene.

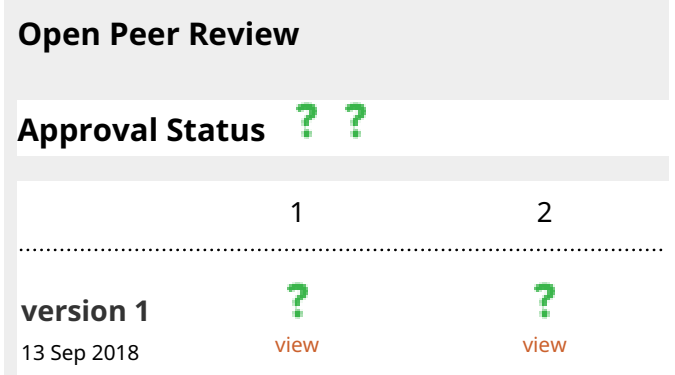

1. Antonella Tosti, University of Miami Miller School of Medicine, Miami, USA

2. Zefferino Palamà iD, Cardiology Unit Casa

di Cura "Villa Verde" Taranto, Taranto, Italy

Any reports and responses or comments on the article can be found at the end of the article. 
Corresponding author: Mehdi Slim (mehdislim_fms@yahoo.fr)

Author roles: Slim M: Conceptualization, Writing - Original Draft Preparation; Neffati E: Writing - Review \& Editing; Lagren A:

Conceptualization, Writing - Original Draft Preparation; Chokri K: Writing - Review \& Editing; Tarmiz A: Conceptualization, Writing Original Draft Preparation; Gribba R: Writing - Review \& Editing; Boughzela E: Writing - Review \& Editing

Competing interests: No competing interests were disclosed.

Grant information: The author(s) declared that no grants were involved in supporting this work.

Copyright: @ $2018 \mathrm{Slim} \mathrm{M}$ et al. This is an open access article distributed under the terms of the Creative Commons Attribution License, which permits unrestricted use, distribution, and reproduction in any medium, provided the original work is properly cited.

How to cite this article: Slim M, Neffati E, Lagren A et al. Case Report: A nine year follow-up for a pacemaker generator poly-tetrafluoro-ethylene coating for allergic reactions to pacemaker compounds [version 1; peer review: 2 approved with reservations] F1000Research 2018, 7:1460 https://doi.org/10.12688/f1000research.16014.1

First published: 13 Sep 2018, 7:1460 https://doi.org/10.12688/f1000research.16014.1 


\section{Introduction}

Pacemaker system hypersensitivity is a rare complication of cardiac pacing and diagnosis is usually difficult, and is often delayed $^{1}$. In fact, bacterial infection is initially suspected routinely rather than allergy to the pacemaker components ${ }^{1}$. Management of this condition is difficult and not well established.

Here, we report a patient who developed repeated sterile skin necrosis leading to generator externalization. Prick testing was of a doubtful interpretation. The patient recovered after implantation of a poly-tetra-fluoro-ethylene (PTFE)-coated pacemaker generator in a retropectoral position.

\section{Case report}

A 75-year-old man with symptomatic complete atrioventricular block received a dual chamber pacemaker (MEDTRONIC SIGMA DR) in November 2000. The patient required two generator re-implantations in March 2005 and August 2007 due to sterile skin necrosis with externalization of the pacemaker generator. A St Jude Medical IDENTITY DR pacemaker was used in the two replacements.

In May 2009, the patient presented with a third externalisation of the pacemaker generator, with localized swelling and redness in the implanted area. The patient had no fever, and inflammatory parameters during blood testing were negative; except the patient had a high eosinophil fraction $\left(0.59 \times 10^{3} / \mathrm{L}\right.$; normal range: $0.0-0.5 \times 10^{3} / \mathrm{L}$ ). Blood cultures, bacterial swabs and cultures of the material taken gave negative results. Swabs from pacemaker pocket showed that C-reactive protein and procalcitonin were negative. We performed a skin prick test using a standard battery (not including titanium). Little positivity was found to nickel and chrome batteries, but skin application of another pacemaker generator (St Jude Medical IDENTITY DR) produced a suggestive skin response.

The patient underwent removal of the old pacemaker system and re-implantation of a new pacemaker system. The generator (Saint Jude Medical Victory XLDR) was entirely coated with PTFE sheet and implanted in the left chest wall in a retro pectoral position (Figure 1). The procedure was uneventful and the patient was discharged in good condition.

After 23 months of regular follow-up, the generator moved from a retropectoral to a subcutaneous position on chest CT scan. No recurrence of externalization or cutaneous signs was observed up to nine years after implantation

\section{Discussion}

Pacemaker component allergy is a rare but well established complication of cardiac pacing. It was first reported by Raque and Goldschmidt ${ }^{2}$ in 1970 in a patient presenting with eczematous dermatitis developed overlying the pacemaker site within 3 weeks of implantation. Since then various reports have been published ${ }^{3,4}$. Several clinical presentations are observed varying from local pain to systemic manifestations. Pacemakermediated dermatitis is thought to be a delayed hypersensitivity type 3 or 4 mediated reaction ${ }^{5}$. The time taken for sensitivity

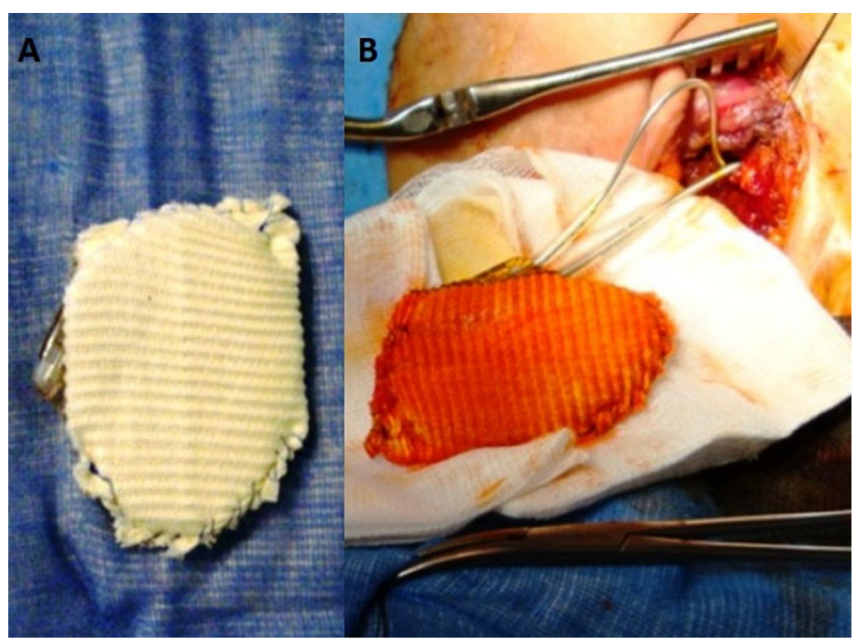

Figure 1. Poly-tetra-fluoro-ethylene (PTFE)-coated pacemaker implantation. (A) Entirely coated pacemaker generator with PTFE sheet; (B) coated generator connected to two leads implanted in retropectoral position.

to develop varies from months to years ${ }^{5}$. In our case, the allergic process occurred several years after implantation. The allergen can be located in the "CAN" or other components of the pacing system. Titanium, nickel and epoxy resin are the most common allergens ${ }^{6}$.

Diagnosis of pace maker allergy is difficult and infection must be ruled out before any hypersensitivity investigation. Skin patch tests are helpful but not always contributive since their sensitivity is not very high. In our patient, skin tests showed a doubtful reaction to nickel and chrome. Titanium is the main component of pacemaker generator, is not included in the standard battery and was very likely to be an allergen because skin reaction was only observed above the generator. Otherwise, Déry and colleagues ${ }^{6}$ suggested that titanium test is unreliable because this test is performed using titanium tetrachloride, which must be highly diluted with water and quickly hydrolyzed to insoluble titanium dioxide. A positive reaction to nickel can be found in up to $20 \%$ of the population ${ }^{7}$; therefore nickel tests should be interpreted with caution. Furthermore, skin tests reading can be extended to 72 hours to have more positive results $^{8}$. A positive reaction to intracutaneous testing on the affected patient's serum incubated with small pieces of titanium for 1 month in a patient who had negative results on patch testing to titanium was reported by Yamauchi et al. ${ }^{9}$. In our patient, clinical presentation is very suggestive of hypersensitivity and titanium is very likely to be an allergen because skin reaction was only observed above the generator (composed mainly of titanium).

Treatments of contact dermatitis have been described in various case reports. There is a role for topical corticosteroid that can reduce skin symptoms, but recurrence is common ${ }^{10}$. The only complete treatment is the removal of the allergen, and the use of a hypoallergenic material. One option, as described by Syburra 
et al. and Andrews and Scheinman ${ }^{1,11}$, is the use of gold-coated generator. PTFE sheet coating technique was first reported in $\mathrm{Japan}^{8,12-14}$. This technique seems to be an effective method despite theoretical risk of PTFE hypersensitivity. In our patient, lack of recurrence confirms pacemaker component allergy and effectiveness of PTFE coating to prevent it.

\section{Conclusion}

Although pacemaker allergy is a rare condition, its recognition is important considering the widespread use of pacing and defibrillation systems. Allergic reaction can occur early or be delayed. It is recommended to rule out this diagnosis in the case of pacemaker pocket inflammation without signs of an infection. A negative skin test should not exclude diagnosis. We report in the present case that removal of the system components and the use of PTFE-coated materials are effective to prevent recurrence with a long follow-up.

\section{Consent}

Written informed consent for publication of the clinical details and images was obtained from the patient.

\section{Data availability}

All data underlying the results are available as part of the article and no additional source data are required.

\section{Grant information}

The author(s) declared that no grants were involved in supporting this work.
1. Syburra T, Schurr U, Rahn M, et al.: Gold-coated pacemaker implantation after allergic reactions to pacemaker compounds. Europace. 2010; 12(5): 749-50. PubMed Abstract | Publisher Full Text

2. Raque $\mathrm{C}$, Goldschmidt $\mathrm{H}$ : Dermatitis associated with an implanted cardiac pacemaker. Arch Dermatol. 1970; 102(6): 646-649. PubMed Abstract | Publisher Full Text

3. Peters MS, Schroeter AL, van Hale HM, et al.: Pacemaker contact sensitivity. Contact Dermatitis. 1984; 11(4): 214-218. PubMed Abstract | Publisher Full Text

4. Hayes DL, Loesl K: Pacemaker component allergy: case report and review of the literature. J Interv Card Electrophysiol. 2002; 6(3): 277-278. PubMed Abstract | Publisher Full Text

5. Raja Y, Desai PV, Glennon PE: Pacemaker-mediated dermatitis. Europace. Images in Electrophysiology. 2008; 10(11): 1354. PubMed Abstract | Publisher Full Text

6. Déry JP, Gilbert M, O'Hara G, et al.: Pacemaker contact sensitivity: case report and review of the literature. Pacing Clin Electrophysiol. 2002; 25(5): 863-865. PubMed Abstract | Publisher Full Text

7. Torres F, das Graças M, Melo M, et al:: Management of contact dermatitis due to nickel allergy: an update. Clin Cosmet Investig Dermatol. 2009; 2: 39-48. PubMed Abstract | Publisher Full Text | Free Full Text

8. Ishii K, Kodani E, Miyamoto S, et al:: Pacemaker contact dermatitis: The effective use of a polytetrafluoroethylene sheet. Pacing Clin Electrophysiol. 2006; 29(11):
1299-1302.

PubMed Abstract | Publisher Full Text

9. Yamauchi R, Morita A, Tsuji T: Pacemaker dermatitis from titanium. Contact Dermatitis. 2000; 42(1): 52-3. PubMed Abstract

10. Skoet $\mathrm{R}$, Tollund $\mathrm{C}$, Bloch-Thomsen PE: Epoxy contact dermatitis due to pacemaker compounds. Cardiology. 2003; 99(2): 112. PubMed Abstract | Publisher Full Text

11. Andrews ID, Scheinman P: Systemic hypersensitivity reaction (without cutaneous manifestations) to an implantable cardioverter-defibrillator. Dermatitis. 2011; 22(3): 161-4.

PubMed Abstract

12. Tamenishi A, Usui $\mathrm{A}$, Oshima $\mathrm{H}$, et al.: Entirely polytetrafluoroethylene coating for pacemaker system contact dermatitis. Interact Cardiovasc Thorac Surg. 2008, 7(2): $275-277$

PubMed Abstract | Publisher Full Text

13. Vodiskar J, Schnöring H, Sachweh JS, et al:: Polytetrafluoroethylene-coated pacemaker leads as surgical management of contact allergy to silicone. Ann Thorac Surg. 2014; 97(1): 328-9. PubMed Abstract | Publisher Full Text

14. Iguchi $\mathrm{N}$, Kasanuki $\mathrm{H}$, Matsuda $\mathrm{N}$, et al.: Contact sensitivity to polychloroparaxylene-coated cardiac pacemaker. Pacing Clin Electrophysiol. 1997; 20(2 Pt 1): 372-3.

PubMed Abstract | Publisher Full Text 


\section{Open Peer Review}

\section{Current Peer Review Status: ? ?}

\section{Version 1}

Reviewer Report 26 June 2020

https://doi.org/10.5256/f1000research.17491.r65545

(C) 2020 Palamà Z. This is an open access peer review report distributed under the terms of the Creative Commons Attribution License, which permits unrestricted use, distribution, and reproduction in any medium, provided the original work is properly cited. The author(s) is/are employees of the US Government and therefore domestic copyright protection in USA does not apply to this work. The work may be protected under the copyright laws of other jurisdictions when used in those jurisdictions.

\section{Zefferino Palamà}

Cardiology Unit Casa di Cura "Villa Verde" Taranto, Taranto, Italy

It is very important to consider patient's body mass index in order to consider an eventual mechanical/compression skin erosion. In fact a retro pectoral implant in these cases could prevent skin erosion.

That consideration should part of discussion and limitations of the case.

The work is well written and very interesting for community.

Is the background of the case's history and progression described in sufficient detail? Yes

Are enough details provided of any physical examination and diagnostic tests, treatment given and outcomes?

Partly

Is sufficient discussion included of the importance of the findings and their relevance to future understanding of disease processes, diagnosis or treatment?

Yes

Is the case presented with sufficient detail to be useful for other practitioners? Yes

Competing Interests: No competing interests were disclosed.

Reviewer Expertise: EHra EP specialist (electrophysiologist) 
I confirm that I have read this submission and believe that I have an appropriate level of expertise to confirm that it is of an acceptable scientific standard, however I have significant reservations, as outlined above.

Reviewer Report 08 March 2019

https://doi.org/10.5256/f1000research.17491.r39381

(C) 2019 Tosti A. This is an open access peer review report distributed under the terms of the Creative Commons Attribution License, which permits unrestricted use, distribution, and reproduction in any medium, provided the original work is properly cited.

\section{Antonella Tosti}

Dr. Philip Frost Department of Dermatology and Cutaneous Surgery, University of Miami Miller School of Medicine, Miami, FL, USA

The clinical history and the follow-up are compatible with a contact dermatitis to the Pacemaker compounds but the authors have to explain well which test they did because they wrote "skin prick tests" but probably they did "patch tests". Furthermore, even if the available Titanium preparations for detection of type IV hypersensitivity is currently inadequate, patch testing with titanium and other metals, would be recommended.

Is the background of the case's history and progression described in sufficient detail? Yes

Are enough details provided of any physical examination and diagnostic tests, treatment given and outcomes?

Partly

Is sufficient discussion included of the importance of the findings and their relevance to future understanding of disease processes, diagnosis or treatment?

Yes

Is the case presented with sufficient detail to be useful for other practitioners? Partly

Competing Interests: No competing interests were disclosed.

I confirm that I have read this submission and believe that I have an appropriate level of expertise to confirm that it is of an acceptable scientific standard, however I have significant reservations, as outlined above. 
The benefits of publishing with F1000Research:

- Your article is published within days, with no editorial bias

- You can publish traditional articles, null/negative results, case reports, data notes and more

- The peer review process is transparent and collaborative

- Your article is indexed in PubMed after passing peer review

- Dedicated customer support at every stage

For pre-submission enquiries, contact research@f1000.com 